\title{
Natural Pigments as Sensitizers for Dye Sensitized Solar Cells
}

\author{
Ezeoke Jonathan*, Muhammad Yusuf Onimisi, Eli Danladi
}

Department of Physics, Nigerian Defence Academy, Kaduna, Nigeria

Email address:

ezeokechidoziej@gmail.com (E. Jonathan)

${ }^{*}$ Corresponding author

\section{To cite this article:}

Ezeoke Jonathan, Muhammad Yusuf Onimisi, Eli Danladi. Natural Pigments as Sensitizers for Dye Sensitized Solar Cells. Advances in Materials. Vol. 5, No. 5, 2016, pp. 31-34. doi: 10.11648/j.am.20160505.11

Received: July 25, 2016; Accepted: August 5, 2016; Published: August 29, 2016

\begin{abstract}
The performance of dye sensitized solar cells (DSSCs), sensitized with natural pigments extracted from mango (mangifera indica), carica papaya, moringa oleifera leaves and bougainvillea flower was demonstrated. The photoactive electrodes of the various DSSCs were sensitized with aqueous extract of the natural pigments. The resulting photoelectrodes were successfully incorporated into the DSSCs. The photoelectrochemical perfomance of the DSSCs were evaluated under 100 $\mathrm{mAcm}^{-2}$ light intensity with open circuit voltage $\left(V_{O C}\right)$ ranging from 0.36 to $0.49 \mathrm{~V}$ and short circuit current density $\left(J_{S C}\right)$ ranging from 0.0134 to $0.1314 \mathrm{mAcm}^{-2}$. From the photovoltaic performance of the extracts, the Mangifera Indica extract sensitized solar cell gave the best performance with $J_{s c}$ of $0.1314 \mathrm{mAcm}^{-2}, V_{o c}$ of $0.49 \mathrm{~V}$, a fill factor $(F F)$ of 0.59 , and an overall solar energy conversion efficiency $(\eta)$ of $0.038 \%$. The sensitization performance related to the interaction between the dye and $\mathrm{TiO}_{2}$ surface is discussed.
\end{abstract}

Keywords: DSSCs, Natural Dye Extracts, Sensitization, $\mathrm{TiO}_{2}$

\section{Introduction}

There are however concerns on maintaining the usage of fossil fuels as the main source of energy. Basically, energy from fossil fuels faces two problems, the first being the limitation of resources and the second their environmental impact [1]. For these two reasons, there has been an urge to develop sustainable energy solutions. The supply of clean sustainable energy is considered as one of the most important scientific and technical challenges facing humanity in the 21 st century [2]

Among the different alternative power sources existing today, solar energy has the most potential [2]. Several new types of solar cells have been studied and developed. Among them, the dye sensitized solar cell (DSSC). The DSSC is a very attractive choice for utilizing the solar energy, due to its potentially low production cost. In contrast to conventional systems, where the semiconductor works as both the light absorber and charge carrier, the DSSC separates the two functions which facilitate the production of the device. Other advantages with DSSCs are flexibility, short energy payback time and relatively high performance at diffuse light conditions [3].

The DSSC contains several different components: A conducting glass substrate, a mesoporous semiconductor film, a sensitizer, an electrolyte with a redox couple and a counter electrode as shown schematically in figure 1 [1]. The function of the sensitizer is to absorb the incident light, inject the excited electron into the semiconductor, and become regenerated by the redox couple in the electrolyte.

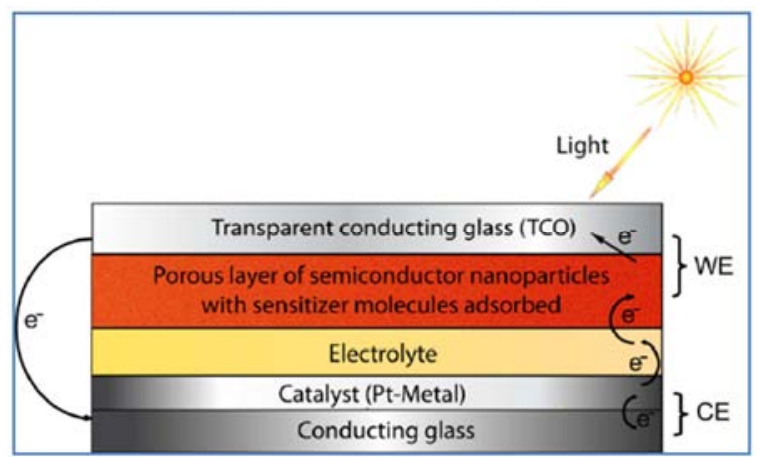

Figure 1. Schematic overview of the Dye sensitized Solar Cell (DSSC). 
The use of natural dyes have been considered as potential candidates to enhance the light response of semiconductor in active layers of solar cells and have been demonstrated in several solar cell materials [4-17]

In this study, Four types of natural dyes were extracted from flowers and leaves such as carica papaya, mangifera indica, moringa oleifera leaves and Bougainvillea spectabilis flower. These extracted dyes were characterized by UV-vis absorption spectra. The photoelectrochemical properties of the DSSCs using these extracts as sensitizers were investigated. The results from the sensitization performance shows that, the DSSC sensitized with the extract of mangifera Indica outperformed the other DSSCs sensitized with other natural dyes in this research work.

\section{Experiment}

\subsection{Extraction of Natural Dyes}

$50 \mathrm{~g}$ of the fresh leaves of (Mangifera Indica, carica papaya, and moringa oleifera), and flower of (Bougainvillea spectabillis) were collected each. The collected leaves of Mangifera Indica, moringa oleifera, carica papaya and the flower of Bougainvillea spectabillis were grinded to small particles using a blender with $100 \mathrm{ml}$ deionized water each as extracting solvent. The solution was filtered to separate the solid from the pure liquid.

\subsection{DSSCs Assembling}

The FTO (solaronix) glass were first cleaned in detergent solution using an ultrasonic bath for 10 minutes, rinsed with deionized water and ethanol, and then dried. The photoanode was prepared by first depositing a blocking layer on the FTO glass, followed by the nanocrystalline $\mathrm{TiO}_{2}$ (solaronix). The blocking layer was deposited from a $2.5 \mathrm{wt} \% \mathrm{TiO}_{2}$ precursor and was applied to the FTO glass substrate by spin coating and subsequently sintered at $400^{\circ} \mathrm{C}$ for 30 mins. The $9 \mu \mathrm{m}$ thick nanocrystalline $\mathrm{TiO}_{2}$ layer was deposited by screen printing. It was then sintered in air for $30 \mathrm{mins}$ at $500^{\circ} \mathrm{C}$. The sintered photoanodes was sensitized by immersion in the sensitizer solution at room temperature overnight. The photoanode and the screen printed platisol counter electrodes were assembled to form a DSSC by creating a gap of $50 \mu \mathrm{m}$ inbetween the two electrodes to be filled with $50 \mathrm{mmol}$ of iodide/tri-iodide dissolve in acetonitrile.

\subsection{Characterization and Measurement}

The current-voltage $(J-V)$ characteristics of the cells were recorded under an irradiance of $100 \mathrm{mw} / \mathrm{cm}^{2}$ (AM1.5) simulated illumination (Keithley 2400 source meter from a Newport A solar simulator). The film morphology of the $\mathrm{TiO}_{2}$ was obtained by scanning electron microscope (Phenom Pro $\mathrm{X}$ model, Eindhoven de Netherlands). The absorption spectra of the dye were recorded on Ava-spec-2048 spectrophotometer in the region of $350-1000 \mathrm{~nm}$. The effective irradiated area of each cell was $1.75 \mathrm{~cm}^{2}$.

\section{Results and Discussion}

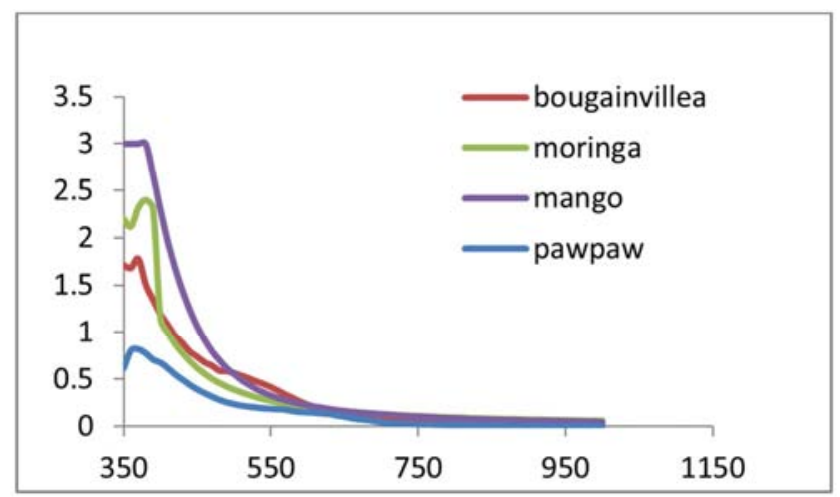

Figure 2. Absortion spectra of bougainvillea flower, moringa oleifera leaves, mangifera indica leaves and carica papaya leaves extract.

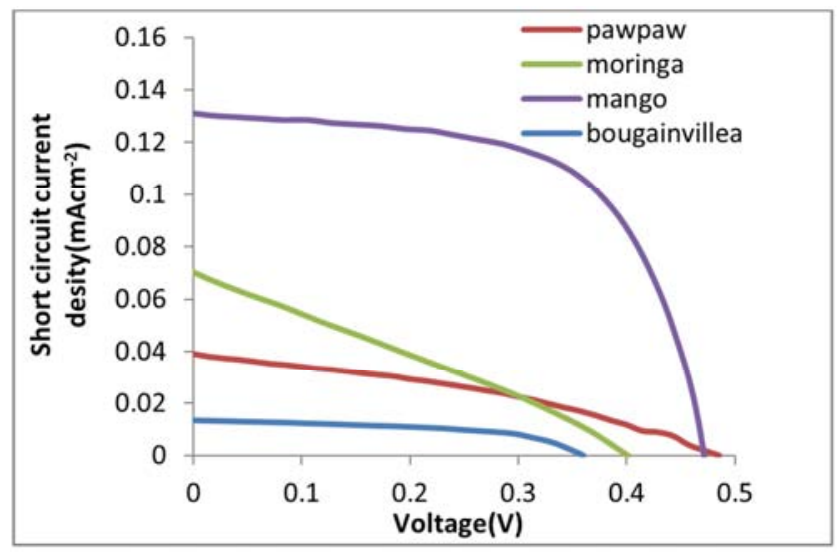

Figure 3. Photocurrent density-voltage $(\mathrm{J}-\mathrm{V})$ curve under $100 \mathrm{mWcm}^{-2}$ light intensity.

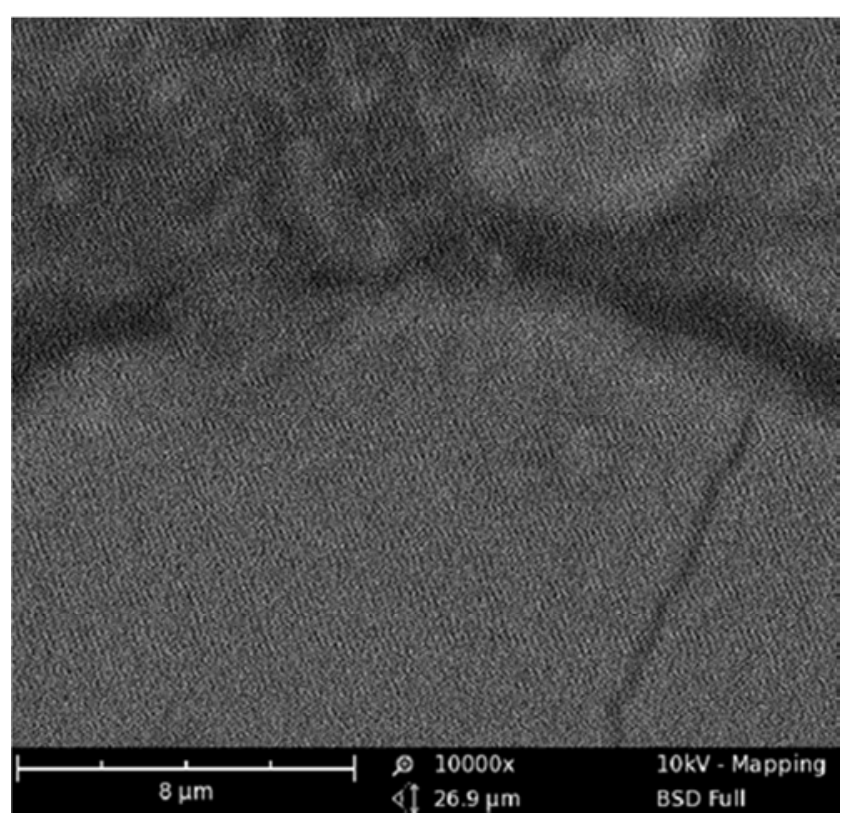

Figure 4. The Scanning electron microscope surface morphology of $\mathrm{TiO}_{2}$ sample.

Figure 3 shows the photocurrent density-voltage $(J-V)$ curves of the DSSCs with different sensitizers. Based on the 
curves in Figure 3, the fill factor (FF) and solar cell efficiency $(\eta)$ were determined using equations (1) and (2) respectively.

$$
\begin{gathered}
F F=\frac{P_{\max }}{P_{\text {in }}}=\frac{J_{\max } \times V_{\max }}{J_{S C} \times V_{O C}} \\
\eta=\frac{F F \times J_{S C} \times V_{O C}}{P_{\text {IRRADIANCE }}} .100 \%
\end{gathered}
$$

Where $V_{\max }=$ maximum voltage $(\mathrm{V}) ; J_{\max }=$ maximum current density $\left(\mathrm{mA} / \mathrm{cm}^{2}\right) ; J_{s c}=$ short circuit current density $\left(\mathrm{mA} / \mathrm{cm}^{2}\right) ; V_{o c}=$ open circuit voltage $(\mathrm{V})$ and $P_{\text {IRRADIANCE }}=$ light intensity $\left(\mathrm{mW} / \mathrm{cm}^{2}\right)$

Figure 2 shows the representative UV-vis absorption spectra for aqueous extract of bougainvillea flower, moringa oleifera, carica papaya and mangifera indica leaves. The extract of bougainvillea spectabilis exhibits an absorption peak of $370 \mathrm{~nm}$. This absorption is attributed to the presence of indicaxanthin, and betacyanin pigment. The extracts of Mangifera indica, Moringa oleifera and Carica papaya leaves (Figure 2), shows absorption peaks at $360 \mathrm{~nm}, 400 \mathrm{~nm}$ and $360 \mathrm{~nm}$. The chemical adsorption of these dyes is accepted to occur because of the formation of bond with the surface of nanostructured $\mathrm{TiO}_{2}$ [7].

Photovoltaic test of DSSCs using these natural dyes as sensitizers are summarized in Table 1. The performance of the natural dyes as sensitizers in DSSCs were evaluated by short circuit current density $\left(J_{S C}\right)$, open circuit voltage $\left(V_{O C}\right)$, fill factor $(F F)$, and energy conversion efficiency $(\eta)$.

Table 1. Photovoltaic performance of DSSC with different sensitizer under $100 \mathrm{mWcm}^{-2}$.

\begin{tabular}{lllll}
\hline Samples & $\mathbf{J}_{\text {SC }}\left(\mathbf{m A c m}^{-2}\right)$ & $\mathbf{V}_{\text {OC }}(\mathbf{V})$ & $\boldsymbol{F F}$ & $\boldsymbol{\eta ( \% )}$ \\
\hline Bougainvillea & 0.0134 & 0.360 & 0.514 & 0.0025 \\
M. Indica & 0.1314 & 0.490 & 0.595 & 0.0380 \\
Carica papaya & 0.0401 & 0.490 & 0.350 & 0.0068 \\
Moringa & 0.0682 & 0.402 & 0.286 & 0.0078 \\
\hline
\end{tabular}

From the effective area of $1.75 \mathrm{~cm}^{2}$, the efficiency of the DSSC sensitized by the mangifera Indica, was significantly higher than the DSSC sensitized by other natural dyes in this studies. It gives a $J_{S C}$ of $0.0134 \mathrm{mAcm}^{-2}, V_{O C}$ of $0.49 \mathrm{~V}, F F$ of 0.595 yielding an efficiency of $0.038 \%$. This better performance is attributed to the higher intensity and broader range of the light absorption of the extract on $\mathrm{TiO}_{2}$ and the higher interaction between $\mathrm{TiO}_{2}$ and the pigment which lead to better electronic coupling and electron transfer [10]. The mangifera Indica extract, has a good and broader absorption in the visible spectrum which is expected to show a good rectification of $J-V$ curve that is responsible for good current density and power efficiency [11].

It was once demonstrated that DSSCs based on anodes containing Bougainvillea spectabilis, mangifera indica, and carica papaya extracts showed photoelectrochemical perfomances of $\left(J_{S C}=0.088 \mathrm{mAcm}-2, V_{O C}=0.20 \mathrm{~V}, F F=\right.$
0.374 and $\eta=0.0066 \%)[18],\left(J_{S C}=0.114 \mathrm{mAcm}-2, V_{O C}=\right.$ $0.433 \mathrm{~V}, F F=0.570$ and $\eta=0.049 \%)$ [7]. and $\left(J_{S C}=0.094\right.$ $\mathrm{mAcm}-2, V_{O C}=0.43 \mathrm{~V}, F F=0.544$ and $\eta=0.022 \%$ ) [10]. When compared to our results with Bougainvillea extract sensitized DSSC, it is in agreement with Yirga et al [18], which recorded an improvement of $56.25 \%$ in efficiency. This improvement is attributed to the differences in phytoconstituents in different part of the plant. Also, when compared to Eli et al [10], their results was higher than our own result with $29 \%$, which is also attributed to the differences in phytoconstituents in different part of the plant which results to aggregated dyes or non-injecting dyes at the surface of the $\mathrm{TiO}_{2}$ that leads to small solar to electricity conversion efficiency. When the result of Kimpa et al [19]; $\left(J_{S C}=0.649 \mathrm{mAcm}-2, V_{O C}=0.503 \mathrm{~V}, F F=0.605\right.$ and $\eta=$ $0.2 \%$ ) was compared to our results, it outperformed our own result which is due to the dye extracting solvent (ethanol in their research and water in our studies) which indicates that the interaction between the $\mathrm{TiO}_{2}$ film and the hydroxyl functions should bring a stronger electron transfer reaction.

\section{Conclusions}

The performance of dye sensitized solar cells with four natural dyes from leaves and flower was demonstrated. The dyes contained chlorophyll, indicaxanthin, and betacyanin pigments. The DSSCs fabricated using the extracted dyes show the $V_{O C}$ varying from 0.36 to $0.49 \mathrm{~V}$ and the $J_{S C}$ ranged from 0.0134 to $0.1314 \mathrm{mAcm}^{-2}$. Among the four dyes investigated, the extract obtained from mangifera Indica showed the best sensitization effect. Since the natural dye extracts, are generally, a mixture of several pigment, therefore the possible reason for the observed differences in sensitization action of the dyes is their varied abilities towards adsorption onto the semiconductor surface. The poor performance noticed in other natural pigment in this study is due to nonelectron injection or the steric hindrance preventing the dye molecule from effectively arraying on the semiconductor film which leads to weaker binding between the dye and the $\mathrm{TiO}_{2}$.

\section{References}

[1] Karl Martin Karlsson, 2011: "Design, Synthesis and Properties of Organic Sensitizers for Dye Sensitized Solar Cells", KTH Chemical Science and Engineering, Royal Institute of Technology, SE-100 44 Stockholm, Sweden.

[2] Lewis, N. S., Nocera, D. G., Proc. Natl. Acad. Sci. 2006, 103 (43), 15729-15735.

[3] Hagfeldt, A., Boschloo, G., Sun, L. C., Kloo, L., Pettersson, H., Chem. Rev. 2010, 110 (11), 6595-6663.

[4] Eli Danladi, M. Y. Onimisi, S. G. Abdu, P. M. Gyuk and Ezeoke Jonathan. Enhanced Performance of a Dye Sensitized Solar Cell Using Silver Nanoparticles Modified Photoanode. Journal of Scientific Research \& Reports. 2016; 10 (4): 1-8. 
[5] Eli Danladi, Muhammad Sani Ahmad, Ayiya Bitrus Bikimi and O. A. Babatunde. Plasmonic Dye Sensitized Solar Cells Incorporated with $\mathrm{TiO}_{2}-\mathrm{Ag}$ Nanostructures. International Research Journal of Pure \& Applied Chemistry. 2016; 11 (3): $1-7$.

[6] M. Y. Onimisi, Eli Danladi, S. G. Abdu, H. O. Aboh and Ezeoke Jonathan. Size Effects of Silver Nanoparticles on the Photovoltaic Performance of Dye Sensitized Solar Cells. American Chemical Science Journal. 2016; 13 (3): 1-8.

[7] Eli Danladi, Ezeoke Jonathan, M. S. Ahmad, Danladi Ezra, S. H. Sarki, Ishaya Iliyasu, and P. M. Gyuk. Photoelectrochemical Performance of Dye-Sensitized Organic Photovoltaic Cells Based on Natural Pigments and WideBandgap Nanostructured Semiconductor. Physical Science International Journal. 2016; 10 (2): 1-7.

[8] Eli Danladi, M. Y. Onimisi, S. G. Abdu, Ezeoke Jonathan and S. O. Yakubu. Photoelectric Characterization of a Dyesensitized Solar Cell Based on Natural Pigment Extracted from Roselle (Hibiscus sabdariffa) Flower and $\mathrm{TiO}_{2}$ Nanoparticles. British Journal of Applied Science \& Technology. 2016; 15 (2): 1-6.

[9] Haruna Isah, Eli Danladi, Gyuk PM. Development of organic dye sensitized solar cell incorporated with $\mathrm{TiO}_{2}$ nanostructures with low conversion efficiency for exploring solar energy concepts. International Journal of Optoelectronic Engineering. 2015; 5 (1): 16-19. DOI: 10.5923/j.ijoe.20150501.03.

[10] Eli Danladi, Muhammad Ahmad, Idodo Maxwell, Danladi Ezra, Aungwa Francis, Sunday Sarki. Dye-Sensitized Solar Cells Using Natural Dyes Extracted from Roselle (Hibiscus Sabdariffa) Flowers and Pawpaw (Carica Papaya) Leaves as Sensitizers. Journal of Energy and Natural Resources. 2016; 5 (1): 11-15, doi: 10.11648/j.jenr.20160501.12.

[11] Eli Danladi, Joshua Adeyemi Owolabi, Gabriel Olawale Olowomofe, Ezeoke Jonathan. Plasmon-Enhanced Efficiency in Dye Sensitized Solar Cells Decorated with Size-Controlled Silver Nanoparticles Based on Anthocyanins as Light Harvesting Pigment. Submitted for publication in Journal of Photonic Materials and Technology.
[12] Eli Danladi, JA Owolabi, GO Olowomofe, MY Onimisi and Aungwa Francis. Enhancement in Photovoltaic Parameters of a Dye Sensitized Solar Cell by Surface Plasmon Resonance of Metallic Silver Nanoparticles. American Chemical Science Journal. 2016; 14 (3): 1-8.

[13] Adenike Boyo, Okafor Paul, Ibrahim Abdulsalami, Oluwole Surukite, Dr H. O. Boyo, Henry Boyo. Application of Hibiscus Sabdariffa and leaves of Azardirachta Indica calyxes as sensitizers in Dye sensitized solar cells. International Journal of Engineering Research and Development. Volume 8, Issue 12 (October 2013), PP. 38-42.

[14] Khwanchit Wongcharee, Vissanu Meeyoo, Sumaeth Chavadej. Dye sensitized solar cell using natural dyes extracted from rosella and blue pea flowers. Front matter Elsevier B. V. 2007.

[15] Barness Chirazo Mphande, Alexander Pogrebnoi. Outdoor photoelectrochemical characterization of dyes from Acalypha wilkesiana 'Haleakala' and Hibiscus sabdariffa as dye solar cells sensitizers. British Journal of Applied Science \& Technology. 2015; 7 (2): 195-204.

[16] Zhou H, Wu L, Gao Y, Ma T. Dye-sensitized solar cells using 20 natural dyes as sensitizers. J. Photobio. A Chemistry 291, 2011. pp 188-194.

[17] Ezeoke Jonathan, M. Y. Onimisi, Eli Danladi, S. G. Abdu and M. S. Abdulsalam. Photovoltaic Perfomance of Dye Sensitized Solar Cells Using Natural Dyes Extracted from Bougainvillea Flower and Mango Leaves. Journal of Scientific Research \& Reports. 2016; 10 (6): 1-5.

[18] Getachew Yirga, Sisay Tadesse, Teketel Yohannes. Photoelectrochmeical cell based on natural pigments and $\mathrm{ZnO}$ nanoparticles. Journal of Energy and Natural Resources. 2016; 5 (1): 1-10. DOI: $10.11648 /$ j.jenr.20160501.11.

[19] Mohammed Isah Kimpa, Musa Momoh, Kasim Uthman Isah, Hassan Nawawi Yahya, Muhammed Muhammed Ndamitso. Photoelectric Characterization of Dye Sensitized Solar Cells Using Natural Dye from Pawpaw Leaf and Flame Tree Flower as Sensitizers. Materials Sciences and Applications, 2012, 3, 281-286. 